\title{
The Illicit Production and Consumption of Ògógóró in Coastal Yorùbáland and the Niger Delta
}

\author{
Dọlápọ̀Z. Olúpàyímọ́ \\ Adeyemi College of Education Ondo, Nigeria \\ olupayimod@gmail.com
}

\begin{abstract}
This article interrogates the production and sale of illicit gin variously called Kái-káí, Rọbìrọbì, Bàbá èrìn, Etonto, Wuru, Push-me-l-push-you, Sáẹpeẹlẹ water, Craze-man-for-bottle, Ògógóró, and Pàrágà in many places including the coastal Yorùbá areas. The places in which it is produced within our area of study include İkọ̀yà, Okitipupa, and İrèlè in İkálẹ land. Other areas in İlàjẹ and Àpọ́iland include Màhíntẹdó, Ugbóńlá, Igbégunrín, and İgbòbíní. The analysis in the article is based on the theory of the political economy and criminality. It is the assumption of this work that as the capitalist mode of production and distribution intensifies, crimes, insecurity and other related issues deepen. The article adopts the use of sources which include oral interviews with resource persons, police information and intelligence reports, newspaper publications and archival documents from the colonial period deposited in the National Archives, Ibadan. As illicitly brewed gin is linked to social deviancy in different ways, and as it can affect peoples' health dramatically, the author argues that the lives of the people should be protected by establishing effective regulatory bodies that stamp out the production of unrated gin.
\end{abstract}

\section{Introduction}

Even though the coastal regions of Nigeria are often primarily associated with the international trade linked to European contact, economic activities relating to food have been very important from time immemorial. As every 
member of the traditional society was first and foremost a farmer ${ }^{1}$, food crops were produced both to take care of local needs and for trade, linking groups primarily involved in arable farming, livestock farming, and those engaged in fishing. ${ }^{2}$ A functioning system of trade routes and markets meant that goods rare in some places were exchanged through trade for others. So important was the food trade that when the British began to stop the export of slaves, palm produce - especially oil - was readily available to take its place. Although other cash crops such as rubber and cocoa were later introduced, palm oil was a flourishing commodity in the uplands of the coastal areas by the nineteenth century.

The origin and proliferation of Ògógóró, a form of local gin, has been traced to the way and manner in which the British administration attempted to stop or discourage the importation of so-called 'trade spirits' through the imposition of the heavy taxes and custom duties. ${ }^{3}$ Instead of reducing the consumption and use of alcohol - as argued by the anti-liquor lobbyists represented by temperance societies, humanitarian evangelicals and other interest groups in Great Britain and the United States of America - higher duties on trade spirits further stimulated the production and consumption of local gin in the Yorùbá coastland. ${ }^{4}$ The scarcity and higher retail price of imported gin during the First World War launched the market for locally produced gin.

Having lost the battle against imported gin through the imposition of heavy taxes and duties, the colonial administration imposed laws on local gin to suppress its production and distribution. ${ }^{5}$ To further fight the production of local gin, various liquor statutes and ordinances were promulgated. However, the liquor statutes, law enforcement personnel, and the law courts deployed to check the production and distribution of local gin seemed to be effective only in the hinterland or in semi-urban areas that were easy to access by colonial administrators or even by the educated African officials who mediated for them.

One reason it was almost impossible to fight the production of local gin was that the use of gin was deeply rooted in local cultural and economic practices

1. I.A. Akínjogbìn, and S.O Òsobà, Topics on Nigeria Economic History (Ilé-Ifè: University of Ife Press, 1980), 23.

2. Ikúèjubè Gbadé, İlàjẹ: The Yorùbá Fishing People of the Niger Delta (Ondó: Novec'kol Publishers, 2005), 1-3.

3. Akin Olórunfémi, "The Liquor Traffic Dillema in British West Africa: The Southern Nigerian Example 1895-1918," International Journal of African Historical Studies, 17 (1984): 229-241.

4. Ovie Felix Forae, "Prohibition of Illicit Alcohol in Colonial Nigeria: A Study in the Tenacity of Ògógóró (Local Gin) in Uhroboland, Southern Nigeria, 1910-1950,” International Journal of Innovative Research, 2.3 (2013), 26.

5. NAI Òkitìpupa Divisional Office (OKITIDIV)1/2/OWC,3P.M. Riley H.P. James, Acting Resident, Oǹdó Province, October, 1935. 
by the time it became subject to government control. ${ }^{6}$ These included the difficulty of accessing areas of production by the law enforcement officers, inadequate numbers and training of law enforcement personnel and equipment, local sabotage, and evasion. Given that many local people had full knowledge of the health hazards associated with the consumption of Ògógóró, one would assume that its outlawing by the colonial government would have been embraced with little or no resistance. But because of the economic advantages of the trade in Oggógóró, this was not the case.

It is against this backdrop that the article interrogates the production, distribution and consumption of local gin variously called Kái-káí, Ògógóró, and Pàrágà. The author visited some of the places where this gin continues to be produced in the coastal Yoruba areas of İkọyà, Òde-İdèpé, Òkìtìpupa, İgbìnsìn-Ọlọ́tọ̀, Igbóbì, and İrèlè; all in İkálẹland. Areas in Îlàjẹ and Àpọiland visited were Màhíntẹdó, Ugbóńlá, Igbégunrín, Igbólómi, and İgbòbíní.

\section{Theoretical Framework}

Given the focus and thrust of this article, the Marxist theory of political economy is not only relevant but also adequate and appropriate for the analysis and understanding of the context in which criminality is discussed. It has been established that criminality is a product of socio-political and in some cases religious contradiction. ${ }^{8}$ It is deeply rooted in people's relationships to the means of production, class struggle and other related inequalities. A careful examination of the exploitative relationships between the few powerful, wealthy people and the numerous poor and powerless masses reveals that there is always a link between criminality and people's relations to the means of production. Criminality is often linked to the desperate efforts of the poor to find a means of subsistence. ${ }^{9}$

Crime is a social reality and the Marxist paradigm has continued to offer a germane starting point to discussing its spread in any given society. In the opinion of William Chambliss, the character of human values derives from the existing patterns of socio-economic production and distribution. ${ }^{10}$ Graham traces the pain and pleasure, security and insecurity, violence and peace, de-

6. NAI "Illicit Distillation" West African Pilot, May 12, (1938) 4.

7. Field notes on work conducted in several coastal Yoruba towns and villages. August 16 and $18,2016$.

8. Karl Marx, Capital: A Critique of Political Economy (New York: Modern Library, 1906).

9. Ibid.

10. William J. Chambliss, “Towards a Political Economy of Crime," Theory and Society, 2.2 (1975): 149-170. 
velopment and underdevelopment as well as crimes to the social hierarchies structuring any given society. ${ }^{11}$ All the aforementioned experiences reflect a combination of the quality of labor, non-human physical resources and interpersonal relations within that society. While individuals continue to seek for ways of escape from poverty and means of expressing themselves in an unfettered manner, they may turn to different crimes. ${ }^{12}$

To explain criminality within the context of the production, distribution and consumption of Ogógóró, this article explores the three-dimensional character of dialectic materialism. The first focus is the dynamic character of social reality which makes it different from the world of non-living things. ${ }^{13}$ That is, when human beings are pushed beyond their limit, the reaction is usually violence; which tends to produce a change. The second is the interrelatedness of different levels of societal strata where one level may not be able to exist independently of the other. That is, a criminal is a criminal because there are people and an environment conducible to committing crimes. ${ }^{14}$ In the absence of such opportunities within the society, there may not be an avenue to express criminal tendencies. The third is the primacy of material conditions. The implication of this statement is that, if there are no material things to pursue, there may not be the need to acquire them. ${ }^{15}$ Hence the struggle to acquire things also has its roles in the breeding of criminal tendencies.

\section{The Consumption of Alcohol in Coastal Yorùbáland}

There are numerous alcoholic beverages all over West Africa and in fact among the Yorùbá people alone, there is Emu, ${ }^{16}$ Ògùrọ,${ }^{17}$ Àgàdàngídí, ${ }^{18}$ and Otikà. ${ }^{19}$ Although all these alcoholic beverages have been known to the coastal Yoruba people and their neighbors for hundreds of years, its usage was usually

11. J.M. Graham, "Profit at all Cost: Amphetamine Profits on Capitol Hill”, Transaction, (1972): 14-24.

12. Ibid.

13. Rohn Clapp, "A Different Outlook on Marxist Philosophy: An Introduction to Dialectical Materialism," http://britanica.com/topic/dialectical-materialism, accessed 1st October, 2016; www.marxism.org.uk/pack/dialectics.html, accessed 1st October, 2016.

14. Rohn Clapp, "A Different Outlook".

15. Ibid.

16. Ẹmu is the Yorùbá name of Palm wine tapped from regular palm trees.

17. Ògùrọ̀/Ògọ̀rọ̀ is the Yorùbá name for the variety of palm wine tapped from Raffia palm.

18. Àgàdàngídí is the Yorùbá name for an alcoholic beverage brewed from plantain.

19. Otíkà is the Yorùbá name for another alcoholic beverage brewed from fermented millet or maize. 
carefully regulated. ${ }^{20}$ The drinking of alcohol was culturally tolerated as part of ceremonial practices. ${ }^{21}$ Children and under-aged youth were not allowed to take alcoholic drinks and in cases where they were permitted to do so, it was under the control of an adult. ${ }^{22}$

Moreover, the consumption of alcoholic beverages was the preserve of men and it played a crucial role in political, religious and socio-cultural relationships. ${ }^{23}$ The Yorùbá society during this period did not permit women to drink alcohol in public. From the corpus of available literature one could almost say that alcohol was not sold in the pre-colonial Yoruba society. However, the present writer found that it would be more accurate to state that alcohol was not commercialized until the colonial era stimulated some degree of competition. ${ }^{24}$ This is because, during the pre-colonial period, the tappers or the brewers had the responsibility to deliver tapped palm wine only to the persons who sent them.

The role played by alcoholic drinks in Yoruba occupied areas included fostering communal unity and friendship. Alcohol was also a key requirement for the consummation of marriages. It was consumed at almost all ceremonies including cultural festivals, chieftaincy enthronements, child dedications and even funerals. ${ }^{25}$ Subsequently, even adult males who were expected to drink were expected to drink responsibly. Yoruba speakers also used alcoholic drinks as a base for the preparation of certain charms or medicinal components. In this regard it served as conduit for the quick conveyance of the medicinal plant or its component to the blood for enhanced medicinal performance. ${ }^{26}$

Alcoholic drinks were also used during religious ceremonies and certain drinks were forbidden to worshipers of certain deities. For instance, adherents of Ọbàtálá are forbidden from taking palm wine. One popular saying in the cognomen of Ògún, the Yorùbá god of iron would corroborate this: Ògún kii șe

20. Dumbili Dumbili, "Changing pattern of alcoholic consumption in Nigeria: An Exploration of Responsible factors and consequences," Journal of Medical Sociology, 7.1 (2013): $20-33$.

21. Heap, Simon. "Those that are Cooking the Gins: The Business of Ogogoro in Nigeria during the 1930s." Contemp. Drug Probs. 35 (2008): 573-610.

22. A Odẹjídé, "Status of Drug use/abuse in Africa: A Review," International Journal of Mental Health and Addiction, 4.2 (2006): 87-102.

23. O.G. Oshodin, "Parental Influence upon Alcohol use by Teenagers in Benin City, Nigeria," Perspectives in Public Health, 104.3 (1984): 106-107.

24. Field notes on work conducted between 16th and 18th August, 2016, in 12 villages and towns in Yoruba coastal areas.

25. O.G. Oshodin, "Nigeria," in B. D. Health, ed., International Handbook on Alcohol and Culture (Westport: Greenwood Press, 1995), 213-223.

26. Oral Interview with Mr. Abednego 56+ in İkòyà on August 17, 2016. 
ọmọ İrè, ẹmu ni Ògún yà mu ní İrè. ${ }^{27}$ Alcohol served as a conduit for social cohesion. This is also true of the Ayélála worshipers who are numerous in the Yoruba coastland. Ayélála worshipers, however, use kolanut and gin, or any other 'hot drink' (spirit). This confirms that more potent alcoholic drinks, such as gin or schnapps, were known and popular locally before the advent of colonial rule. When gin became scarce, it became very difficult to appease Ayélála. ${ }^{28}$

In the Yoruba coastal area, where the environment is cooler than inland, younger people were allowed to drink more than their counterparts upcountry because alcohol was believed to help people warm up. However, it is possible that lower checks on alcohol consumption also reflected the easier availability of European trade spirit. ${ }^{29}$ Even so, alcohol was always consumed under the supervision of adult males. ${ }^{30}$ Moreover, alcoholic drinks were always associated with special occasions or medical prescriptions. ${ }^{31}$ It must be stressed that even consumption by elders was controlled. For instance, the size of cups depends on both the person drinking and the degree of fermentation of the drink in use. ${ }^{32}$

\section{The process of Ògógóró production and innovation}

The rise of illegal Ògógóró production appears to be a development of the early colonial period. A brief examination of the possible origin of illegal Ògógóró production in Nigeria and consequently in the Yorùbá coastal regions suffices to point out how it may be linked to the colonial political economy. Standing on the platform of our first dimension of explanation from dialectic materialism, the prohibition of gin imports in the early period of colonial rule, and the collapse of cash-crop economy in Nigeria during the period of international economic recession of 1929-33 made it difficult for indigenes to be able to patronize imported trade spirit. ${ }^{33}$

27. This simply translates as: Ògún is not a native of İrè, he only had a stop-over at İrè to drink palm wine.

28. Oral Interview with Mrs. Ikúènógbón 68 at Òde Aye, a village in İkálẹland on $16^{\text {th }}$ August, 2016.

29. Akin Olórunfémi, “The Liquor Traffic Dillema in British..., 229.

30. I.S. Obot, "Developing Countries ignore Drinking and Driving Problems at their own Peril," Addiction, 107 (2012): 1209-1210.

31. A. Ibanga et al., "The contexts of alcohol consumption in Nigeria," Isidore S. Obot \& Robin Room (eds), Alcohol, Gender and Drinking Problems: Perspectives from Low and Middle Income Countries, (Geneva: World Health Organisation, 2005) 143-166.

32. Oral Interview with Mr. Mansion, 57+, at Igbóbì Camp in Màhíntẹddó on $17^{\text {th }} \mathrm{Au}-$ gust, 2016.

33. "The Popular Wall Street Crash of 1929-1933," http://www.history.com/topics/1929-stock-market-crash, accessed February 8, 2017. 
According to some traditions, one Stocky James Iso, a native of Calabar, should be credited with the first distillation of Ogógóró in Nigeria. ${ }^{34}$ He worked with Paterson Zochonis (PZ) and later with G.W Griffiths, another British firm. While he was working with these European firms, he had the opportunity to travel to the United States of America (New York) for a period of one year within which he was able to work for three families as a household servant. His trip to New York was undertaken during a period when the Volstead Act was in force, which was the Act that prohibited the production and consumption of alcohol in the United States. ${ }^{35}$ Somehow, Iso learnt the art of distilling Moonshine before his return. Iso was imprisoned for three years between 1929 and 1931 for stealing $£ 95$ from Paterson Zochonis. ${ }^{36}$ By the time he completed his jail term, Iso began to sell his skills in distillation for $£ 25$ per lesson to interested individuals. ${ }^{37}$

Other evidence suggests alternative beginnings of Ògógóró distillation in Nigeria. For instance, it is also possible that it was acquired from hospitals and laboratories where spirits were distilled for medical and scientific purposes. ${ }^{38}$ Others suggested that the knowledge might have been received from an internally circulated police journal that featured pictures of the distillation of local rum in British Guiana in 1929. ${ }^{39}$ However, it is apparent that most of the people arrested and tried by the colonial court in the 1930s could be linked back to either Mr. Iso or a person he trained. ${ }^{40}$

Following Mr Iso's practice, the production of Ògógóró was done through the boiling of fermented palm wine popularly called Pami. In addition to palm wine, the equipment used by the local distillers consisted of simple equipment that could be easily located. These included a dugout canoe, or a carefully designed wooden structure similar to a canoe, a big drum, three or four pieces of connecting copper pipe, water, firewood, and receiving containers.

These were assembled to boil and extract the alcoholic content of the palm wine, and to filter the distillate into the receiving water (see figures 1-3). In the process of boiling the palm wine, the alcohol-containing vapor was controlled and condensed back to a potent liquid form. The final product can be distilled

34. Simon Heap, "'Those who are Cooking the Gin': The Business of Ògógóró in Nigeria During the 1930s," Contemporary Drug Problems, 35.4, (2008): 573-610.

35. Ibid.

36. Ibid.

37. Ibid.

38. Ibid.

39. NAI, A.D.M. White, "Bush Rum in British Guiana," Police Journal, 2 (1929): 211217 cited by S. Heap op. cit.

40. Simon Heap, “Before Star': Manufacturing Western Style Alcohol in Nigeria 18701970," African Economic History, 24 (1996): 69-89. 
many times to increase potency. A minimum of seven 25 liter kegs of palm wine is exposed to between three to four hours of vigorous boiling and the vapor is passed through a wooden pipe into another twelve 25 liter kegs of water. This produces the strong alcoholic drink called "Turn" which is collected into a small 2 liter bottle. This first extract is called "Turn", and it is so strong that it can be diluted with 20 liters of water and will still produce intoxicating Ògógóró.

The Niger Delta, with its many waterways that are difficult to access and control for those not used to marshy environments, offered an ideal place for the illegal production of Ògógóró in large quantities. It is therefore likely that the production of Ògógóró in coastal Yorùbáland was imported from the Niger delta. As locally distilled Ògógóró was cheaper and easily accessible there, it became very popular, to the degree where its patronage as Ògógóró, Káí-káí, or Sápẹ́lé water, is often said to distinguish the ethnic groups of the Niger Delta where it has become a staple since its introduction. ${ }^{41}$

Initially, back in the pre-colonial period, trade spirit was accessible to some people who could afford it. As trade regulations and later the global depression limited its accessibility to very rich people, the distillation of Ògógóró began in earnest. It did not take long and production was made less expensive through the additional use of sugar during fermentation. Later, distillers discovered the use of new alternative ingredients like banana, cashew, cassava, coconut, guinea corn, maize, pineapple, potatoes and yam. In Urhoboland, the bark of the Ugun tree, which gives a reddish colour to the Ògógóró, was often added to add a distinct flavor to the distilled product.

As most distilling takes place in small outfits, individual producers can be creative in the productive process. Another product often added to the palm wine before or during distillation in the Niger delta was soap made from palm oil and ash. This soap was believed to enable distillers to avoid the mixing of palm wine and distillate, which could introduce disorder to the process. ${ }^{42}$ The Figures below illustrate the distillation process and were taken by the author in distilleries at Igbóbì, İdèpé, and Màhíntẹdó.

In the distillation process, expensive copper tubing, which provided a welcome flavor to many drinkers, was also replaced by other implements, including cheaper plastic tubing or even used car parts. Unfortunately, the use of such materials could mean that hazardous chemicals were introduced to the

41. C.J. Korieh, "Alcohol and Empire: Illicit gin Prohibition in Colonial Eastern Nigeria," African Economic History, 31 (2003): 111-34.

42. Felix Forae Ovie, "Prohibition Of "Illicit" Alcohol In Colonial Nigeria: A Study In The Tenacity of Ògógóró (Local Gin) In Urhoboland, Southern Nigeria, 1910 - 1950," International Journal of Innovative Research and Development, 2.3 (2013): 13-33, 20. 


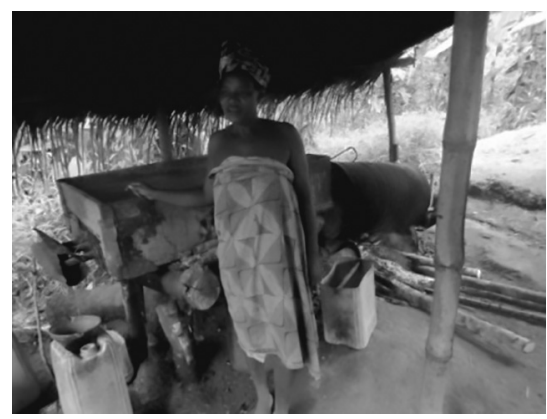

Figure 1. A female distiller supervising the 'cooking' of palm wine, near Igbóbì. Source: (C) Dọlápọ̀ Z. Olúpàyímọ́ 2016.

process of distillation either because the tubing was not clean or because the plastic leached when in contact with highly potent alcohol. Non-copper metal conduit pipes used to convey the distilling vapor into the water that eventually turns to Ògógóró has been proven to have some strong acidic transfer into the Ògógóró. ${ }^{43}$ In many distilleries, the environment was also unhygienic. ${ }^{44}$

Like other spirits, Ògógóró was dangerous because of its high alcohol content. A simple analysis gathered by the present writer suggests that Ògógóró contains at the very minimum 20 per cent of alcohol. ${ }^{45}$ This means that high levels of intoxication are reached quickly, which can lead to vomiting as well as more long-term damage to the health of drinkers. Beyond that, the local innovations in Ògógóró production meant that some distilleries produced spirits

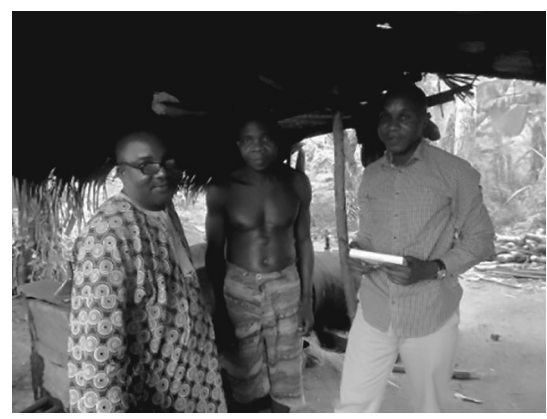

Figure 2. Mr. Amos Paul (centre) discussing aspects of the distillation business at İdèpé . Source: (c) Dọlápọ̀ Z. Olúpàyímọ́ 2016.

43. Conversation with Dr. Loto, A Medical Doctor at Ondo, on the problems of consuming Ògógóró in significant amounts.

44. Oral Interview with Mr. Abednego, 56, at Ikoya on August 17, 2016.

45. Conversation with Dr. Emmanuel Ale, a Medical Doctor at FMC, Owo, Nigeria on $13 / 11 / 2016$. 
that included levels of methanol or other components that were dangerous to consumers' health if imbibed in large quantities, and sometimes the drink produced was outright poisonous.

However, as the various duties and sanctions imposed on trade spirit continue to bite and the economy struggled, Ògógóró became more attractive, until even rich people began to depend on the poor local distillers to secure it. When the colonial government attempted to close illegal distilleries, both to uphold the law and in the interest of public health, producers were often protected and defended by local populations. When the government relied on paid informants (a system only in operation for a short time), informants often abused the system by either denouncing their enemies for personal purposes, or by lying about the location of illegal distilleries and disappearing before their lies were uncovered. ${ }^{46}$

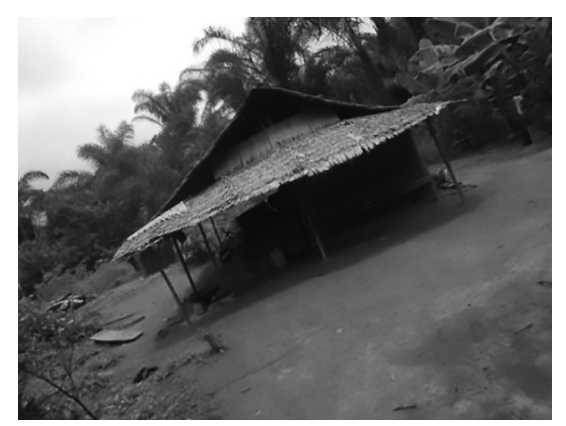

Figure 3: The Factory of Mr. Mansion at Màhíntệdọ́. Source: () Dọlápọ Z. Olúpàyímọ́ 2016.

\section{Ògógóró production, illegality and violence}

The second level of our application of dialectic materialism to the explanation of criminality and the production, distribution and consumption of Ògógóró emphasizes the interrelatedness of different levels of societal strata where one level may not be able to exist independent of the other. The expansion of Ògógóró production, distribution and consumption was gradual, but it was linked to an increasing association with unregulated, harmful, and illegal activity.

The battle against the production of Ògógóró that started in the colonial era ended with the granting of independence, when the locally produced Ògógóró was legalized. As in Ghana and other West African colonies, this decision

46. Felix Forae Ovie, "Prohibition,” 25. 
partly reflected the privileging of economic and political reasons, in the form of tax income and popular demand, over public health. ${ }^{47}$ However, while the quality of Ògógóró should theoretically be controlled by state organs, presently the National Agency for Food and Drug Administration and Control (NAF$\mathrm{DAC}$ ), the fact that many batches are produced without permit or license mean that most Ògógóró is produced illegally. ${ }^{48}$

As mentioned above, the invention of Ògógóró, and the adaptation of the distillation process to local tastes and practices, led to a reduction in the price of spirits. This made concentrated alcohol accessible to both the rich and the poor, and consequently distribution and consumption increased because more people could afford to buy it. However, it seems that until the independence period, the consumption of Ogógóró increased only in minor ways and consumption took place largely within the social patterns that had been associated with alcohol for some time. This, however, changed in the wake of the Civil War (1967-70) and during the country's subsequent oil boom of the 1970s. Many soldiers regularly consumed alcohol, including Ògógóró. As many communities along the coast were affected by the war, whether as battlegrounds, or as army barracks, or as places of refuge for displaced people, existing taboos on alcohol and Ògógóró consumption were lifted.

The oil boom of the 1970s was associated with an increase in consumption across Nigeria, and Ògógóró consumption went up further along with all other types of consumption. ${ }^{49}$ The expanded demand could be met by setting up production in the creeks of the Niger delta, and in other in coastal and riverine areas that were not easy to access by road. Similarly, most trade took place by water. In the early period of independence, Ògógóró was often traded from the Niger Delta and the eastern Lagos lagoon towards Lagos and Ikorodu along with palm oil. As the trade in palm produce and other legal commodities moved increasingly towards the roads, the canoe trade in Ogógóró expanded.

An important advantage of the trade by water was that the traders themselves often knew the waterways much better than the colonial or postcolonial government officials. The colonial River Niger Protective Service, an anti-smuggling outfit empowered to intercept canoes laden with 'illicit' gin, was famously unsuccessful..$^{50}$ After independence, the local advantage remained in existence, because coastal communities often only had few sons and daughters

47. I. Ligunaah, and C. Dakubo, "Consumption and Impact of Local Brewed Alcohol (Akpeteshie) in Upper West Region of Ghana: A Public Health Tragedy," Social Science and Medicine 57.9 (2003), 1747-1760.

48. Oral Interview with Mr. Amos Paul, undisclosed location, August 17, 2016.

49. S.I. Obot, and A. Ibanga, "Selling Booze: Alcohol Marketing in Nigeria," The Globe 2 (2002) 6-10.

50. Felix Forae Ovie, "Prohibition", 26. 
educated enough to go into the police, and upland police officers, often unable to swim, could not match the smugglers' knowledge of local creeks.

Moreover, the Civil War increased the number of highly efficient small arms available in the general population, and smugglers were increasingly able to protect themselves. From the 1980s onwards, criminal groups engaged in more openly illegal activities, such as oil pipe vandalization or oil bunkering, often traded their goods along with Ògógóró, or protected Ògógóró traders. In the 1990s, Oggógóró producers and traders were also protected, and in turn offered financial support to, insurgent or warring groups in the Niger Delta.

Beyond its links to illegal trade networks, the increased consumption of Ògógóró was associated with a decline in social control. Whereas in the past, adults from any community controlled the consumption of alcohol and applied punitive measures to those involved in criminal activity, this is no longer the case. Female drinking, which has increased to often problematic levels, is usually associated with prostitution and by extension to the spread of sexually transmitted diseases. The drinking of young men - including undergraduates - is often associated with rebellion, protest, and social deviancy.

The most frequent pattern of alcohol consumption in Nigeria is heavy episodic drinking (rather than moderate drinking) ${ }^{51}$ In the Nigerian army, the consumption of alcohol has often helped the soldiers to cope with the violence of conflict. There was a similar combination of alcohol and violence among the smugglers and consumers of Ògógóró, as many of the people involved in the unregulated trade in Ògógóró used the drink to fortify themselves during their clandestine trading operations. Others consumed Ogógóró to prepare for criminal activities such as robberies and burglaries, which began to increase in many parts of Nigeria in the mid-1980s and 1990s. ${ }^{52}$ In response, many people who were at threat of such crimes, including lorry and bus drivers and conductors, but also the local vigilantes that sometimes organized to fight against such criminals, equally relied on alcohol as part of the social and spiritual preparation for their tasks.

Ogógóró is also an important drug for most of the rebel groups operating in the Niger Delta. Like soldiers in the 1960s, the members of such groups often drink individually to deal with the stress of battle and evasion. In some groups, they must also drink Ògógóró in order to fit in and prove themselves as real

51. Andree Demers, Robin Room \& Chantal Bourgault, World Health Organization Monograph on Alcohol Epidemiology in Developing Countries- Nigeria, WHO, Department of Mental Health and Dependence, (2000), 63-78.

52. Dolápò Z. Olúpàyímó, “Terrorism, Drug Problems and the use of Psychoactive Substances: A Perspective Examination of the Nigerian Democratic Arena," Unpublished paper presented at an International Conference Jointly Hosted by Historical Society of Nigeria and Adékúnlé Ajáșin University, Àkùngbá-Àkókó, between November 24 and 27, 2015. 
"sons of the soil". In this way, Ògógóró has played its own role in fueling violence linked to insurgence. ${ }^{53}$ Moreover, these insurgent groups are also frequently implicated in kidnapping, oil pipe vandalization, and the bunkering of crude oil are also often linked to high levels of alcohol abuse by the perpetrators.

Today, Ògógóró is sold almost everywhere in Nigeria, but it is a commodity that can always be found in motor parks where public cabs and commuter vehicles are loaded for local and long distance journeys. The present author visited five registered motor parks where commuters are transported around the Yoruba coastland and found that for many consumers, the buying of Ògógóró is acceptable if it takes place under a certain trade name which they trust. ${ }^{54}$ There are also different types of packaging illegitimately used by producers so that the product will seem as if it is legitimized by NAFDAC. As policies on the time, day, place, sale and acquisition of hard liquor either do not exist or are not enforced, sellers can sell Ògógóró to young boys and girls, and even to alcoholics.

\section{Conclusion}

As this article has shown, Ògógóró is linked to crime in several ways. First, the lack of regulation or control over the way in which Ògógóró is produced allows greedy or incompetent producers to offer products that are dangerous and can damage the health of even moderate drinkers. In April 2015, 18 young people, mostly motor-cycle riders, died from the consumption of bad Ògógóró at Ayadi and Irele Local Government area of Ondo State. ${ }^{55}$ In June that year, 38 persons died in Rivers State after consumption of a bad batch of Ògógóró during a celebration at a dog-meat joint. ${ }^{56}$ Afterwards, the National Agency for Food and Drug Administration and Control (NAFDAC) placed a ban on the consumption of the locally-made gin, popularly called Ògógóró. ${ }^{57}$ However, this ban seems to be a formality; it is not enforced and it is possibly unenforceable.

Second, Ògógóró is often traded through distribution networks that are semi-legal or illegal in other ways, usually because they have no NAFDAC

53. "Nigerian rebel leaders give up arms in Amnesty Deal," Reuters, October 3, (2009).

54. Oral Interview with anonymous respondents in Ộrè Motor Park on 23/08/2016, Òkìtìpupa Main Motor Park on 08/23/2016 and at İgbọ́kọddá Market Park on 23/08/2016.

55. "Nigeria: Shocking Truth of How 38 Illicit Gin Drinkers Died," Vanguard Newspaper, June 10, 2015.

56. Ibid.

57. "Ondo deaths: Conflict between traditional beliefs and science," Vanguard Newspaper, April 22, 2015. 
registration and/or avoid taxation of Ògógóró and sometimes other traded goods. As explained above, the consumption of Ògógóró is often associated with rebellious or deviant social activities along the coastal waterways, including the trade in other illegal commodities and the financing of politically or economically subversive activities by violent groups.

Third, the de-facto lack of control over the sale of Ògógóró (where such regulations exist) means that its easy availability may be linked to typical alcohol-related health problems, such as heart disease, ${ }^{58}$ and in the case of Ògógóró especially liver disease. ${ }^{59}$ The injurious power of Ògógóró is particularly evident when 'Turn' is for sale. This is the condensated alcohol produced as the first output from the production machinery, before it is mixed with water. The strength of 'Turn', often between sixty and ninety percent proof, is so injurious to human health that no man could finish a whole glass without falling severely ill.

In conclusion, the present author argues that the Federal Government of Nigeria, through the use of effective information and regulatory bodies, should begin to take steps to stamp out the production of Ògógóró. In collaboration with community and youth leaders in coastal communities involved in the trade, it is hoped that this will help to protect the lives of many innocent people.

58. Ibid.

59. Ibid. 